\title{
Możliwość wyłączenia przez gminę w drodze uchwały odbioru odpadów komunalnych z nieruchomości niezamieszkałej oraz zobowiązania do zawarcia umowy indywidualnej z podmiotem świadczącym usługi odbioru odpadów ${ }^{1}$
}

\author{
A possibility of a commune to exclude, by means of a resolution, \\ communal waste collection from uninhabited real estate and the \\ obligation to conclude an individual agreement with an entity providing \\ waste collection services by a commune
}

\begin{abstract}
A commune has the right to freely shape the communal waste collection system in relation to owners of uninhabited real estate where communal waste is generated. In the event that a resolution regarding this matter is passed on by a commune council, a property owner has the option of being excluded from the system. Such an exclusion obliges the owner of the property to conclude a contract with the communal organisational unit collecting communal waste. The implementation of this statutory obligation imposed on property owners is subject to control by a head of commune, mayor or a president of a city.
\end{abstract}

Keywords: commune, waste

Gmina ma prawo dowolnego kształtowania systemu odbierania odpadów komunalnych w odniesieniu do właścicieli nieruchomości, „na których nie zamieszkują mieszkańcy, a powstają odpady komunalne". W sytuacji podjęcia przez radę gminy uchwały w tej sprawie właściciel nieruchomości ma możliwość wyłączenia się z tego systemu. Wyłączenie takie obliguje właściciela nieruchomości do zawarcia umowy z gminną jednostką organizacyjną odbierającą odpady komunalne. Realizacja tego ustawowego obowiązku właścicieli nieruchomości podlega kontroli przez wójta, burmistrza lub prezydenta miasta.

Słowa kluczowe: gmina, odpady

doktorantka -

Uniwersytet Warszawski, Wydział Prawa i Administracji • natalia.podraza@sejm.gov.pl • https://orcid.org/0000-0001-9817-7696

1 Opinia prawna dotycząca możliwości wyłaczenia przez gmine $w$ drodze uchwały odbioru odpadów komunalnych z nieruchomości niezamieszkałej oraz zobowiązania do zawarcia umowy indywidualnej z podmiotem świadczacym ustugi odbioru odpadów sporządzona 18 marca 2020 r. na zlecenie posła Klubu Parlamentarnego Prawo i Sprawiedliwość; BAS-WAP-522/20. 


\section{Przedmiot opinii}

W złożonym zleceniu zwrócono się z prośbą o przygotowanie opinii prawnej udzielającej odpowiedzi na następujące pytanie: „Czy gmina ma prawo w uchwale o odbieraniu odpadów komunalnych wyłączyć z odbioru odpadów nieruchomość, na której nikt nie mieszka, ale odpady komunalne powstają, ponieważ znajduje się tam sklep i czy ma prawo zobowiązać do zawarcia umowy indywidualnie z podmiotem świadczącym usługi odbioru odpadów?".

Opinia została przygotowana na zlecenie posła Klubu Parlamentarnego Prawo i Sprawiedliwość, przyjęte przez Biuro Analiz Sejmowych 9 marca 2020 r., i uwzględnia stan prawny na dzień jej sporządzenia.

Niniejsza opinia nie odnosi się do konkretnego stanu faktycznego, lecz stanowi analizę stanu prawnego pod kątem problemów wskazanych w zleceniu. Przedstawione w niej stanowisko nie wiąże ani organów władzy publicznej, ani innych podmiotów.

W opinii uwzględniono regulacje następujących aktów prawnych:

- ustawy z dnia 13 września 1996 r. o utrzymaniu czystości i porządku w gminach (t.j. Dz.U. 2019, poz. 2010, ze zm.; dalej również: u.c.p.g. lub ustawa);

- ustawy z dnia 8 marca 1990 r. o samorządzie gminnym (t.j. Dz.U. 2019, poz. 506, ze zm.; dalej: u.s.g.).

\section{Uzasadnienie tez opinii}

Zadania gminy oraz obowiązki właścicieli nieruchomości dotyczące utrzymania czystości i porządku zostały uregulowane ustawą o utrzymaniu czystości i porządku w gminach. Zgodnie z art. 3 ust. 1 u.c.p.g. utrzymanie czystości i porządku w gminach należy do obowiązkowych zadań własnych gminy. Ustawodawca wśród tych obowiązków gminy wskazał m.in. ustanowienie systemu gospodarowania odpadami komunalnymi (art. 3 ust. 2 pkt 3) oraz nadzorowanie funkcjonowania tego systemu (art. 3 ust. 2 pkt 4).

Ustawa o utrzymaniu czystości i porządku w gminach dokonuje podziału właścicieli nieruchomości na dwa typy, wobec których odmiennie został ukształtowany obowiązek gminy dotyczący zorganizowania odbioru odpadów komunalnych. Zgodnie z art. 6c ust. 1 u.c.p.g.: „Gminy są obowiązane do zorganizowania odbierania odpadów komunalnych od właścicieli nieruchomości, na których zamieszkują mieszkańcy”. Natomiast jeśli chodzi o nieruchomości, „na których nie zamieszkują mieszkańcy, a powstają odpady komunalne", rada gminy może w drodze uchwały stanowiącej akt prawa miejscowego postanowić o odbieraniu odpadów komunalnych od właścicieli tych nieruchomości (art. 6c ust. 2 u.c.p.g.).

Uchwała rady gminy zawierająca określone postanowienie dotyczące odbierania odpadów komunalnych od „właścicieli nieruchomości, na których 
nie zamieszkują mieszkańcy", jest aktem prawa miejscowego w rozumieniu art. 40 ust. 1 u.s.g. W przeciwieństwie do obowiązku gminy dotyczącego zorganizowania odbioru odpadów komunalnych od właścicieli zamieszkałych nieruchomości uchwała rady gminy dotycząca objęcia nieruchomości niezamieszkałych systemem odbioru odpadów komunalnych ma charakter fakultatywny. Gmina posiada zatem uprawnienie do dowolnego kształtowania wyżej wymienionego systemu w odniesieniu do właścicieli nieruchomości, „,na których nie zamieszkują mieszkańcy, a powstają odpady”. Jeżeli zatem uchwała nie zostanie wydana, wówczas na terenie gminy będą obowiązywać różne zasady gospodarowania odpadami komunalnymi dotyczące właścicieli nieruchomości zamieszkałych (obowiązujące z mocy prawa) oraz „właścicieli nieruchomości, na których nie zamieszkują mieszkańcy” (te zasady mogą być zmienione wyłącznie uchwałą) ${ }^{2}$.

Należy także wskazać, że uchwała rady gminy w przedmiocie odbierania odpadów komunalnych może zostać podjęta zarówno w stosunku do wszystkich „Właścicieli nieruchomości, na których nie zamieszkują mieszkańcy”, jak i w stosunku do wyłącznie niektórych właścicieli nieruchomości niezamieszkałych, np. właścicieli „nieruchomości na których jest prowadzony określony rodzaj działalności” (art. 6c ust. 3 u.c.p.g.). Objęcie zatem określonych właścicieli nieruchomości niezamieszkałych zorganizowanym przez gminę systemem odbierania odpadów komunalnych jest zależne od treści uchwały rady gminy ${ }^{3}$. Jak wskazuje się w orzecznictwie, „celem przepisu art. 6c u.c.p.g. jest wprowadzenie możliwości dokonania ograniczeń podmiotowych poprzez dopuszczenie wyboru po stronie gminy od właścicieli których nieruchomości niezamieszkałych odpady będą odbierane, a od których nie. Analiza powyższych przepisów, a zwłaszcza art. $6 c$ ust. 3 u.c.p.g., w sposób jednoznaczny prowadzi do wniosku, że gmina ma pełną swobodę w doborze nieruchomości, które chce włączyć do gminnego systemu gospodarki odpadami komunalnymi. Ustawodawca bowiem wyraźnie wskazał, że uchwała w sprawie odbierania odpadów komunalnych od właścicieli nieruchomości, na których nie zamieszkują mieszkańcy, a powstają odpady komunalne, może dotyczyć wszystkich właścicieli nieruchomości lub właścicieli określonych nieruchomości"4.

Jak już wyżej stwierdzono, uchwała w przedmiocie objęcia systemem gospodarowania odpadami „może dotyczyć wszystkich właścicieli nieruchomości lub właścicieli określonych nieruchomości, w szczególności nieruchomości na których jest prowadzony określony rodzaj działalności”. We wskazanym przepisie

2 W. Radecki, komentarz do art. 6(c) [w:] Utrzymanie czystości i porządku w gminach. Komentarz, Warszawa 2016.

3 Wyrok WSA w Olsztynie z dnia 2 października 2019 r., I SA/Ol 498/19, LEX nr 2726562.

4 Postanowienie WSA we Wrocławiu z dnia 13 października 2016 r., II SA/Wr 269/16, LEX nr 2176029. 
ustawodawca, posługując się sformułowaniem „w szczególności”, wskazał jedynie na przykładowy katalog charakteryzujący określone nieruchomości niezamieszkałe i nie wykluczył możliwości dowolnego wyboru przez radę gminy w drodze uchwały grupy właścicieli nieruchomości niezamieszkałych podlegających objęciu gminnym systemem gospodarowania odpadami. Jak wskazuje w swoim orzecznictwie Naczelny Sąd Administracyjny: „Na gruncie reguł wykładni językowej (gramatycznej), użycie zwrotu «w szczególności» pełni co do istoty funkcję uszczegółowienia egzemplifikacyjnego wyrażenia bardziej ogólnego, wskazanego w części wypowiedzi normatywnej, znajdującej się przed zwrotem «W szczególności». Egzemplifikacyjność tego uszczegółowienia polega na tym, że wyliczenia występujące po nim mają charakter przykładowy i określają zwykle szczególne przypadki zjawiska ogólnego. Nawet jeśli nie wyczerpują wszystkich możliwych przypadków, obejmują w jakimś sensie najważniejsze z nich dla określenia istoty właściwości ogólnej”"

Należy także wskazać, że gmina, dokonując wyboru określonych właścicieli nieruchomości niezamieszkałych w celu objęcia ich systemem gospodarowania odpadami komunalnymi, winna swoim działaniem (lub zaniechaniem) nie powodować naruszenia zasady równości, wyrażonej w art. 32 Konstytucji Rzeczypospolitej Polskiej z dnia 2 kwietnia 1997 r. (Dz.U. nr 78, poz. 483, ze zm.). Przepis ten w ust. 1 stanowi, że wszyscy są wobec prawa równi oraz że wszyscy mają prawo do równego traktowania przez władze publiczne. Przez zasadę równości należy rozumieć równe traktowanie podmiotów znajdujących się w tej samej sytuacji prawnej, posiadających (charakteryzujących się) daną cechę istotną $\mathrm{w}$ równym stopniu. Zasada równości wobec prawa może mieć odniesienie zarówno do skutków podziału, co oznacza obowiązek równego traktowania wszystkich podmiotów zaliczonych do tej samej kategorii ustalonej ze względu na przypisanie im wspólnej istotnej cechy, jak i do kryteriów zaliczania określonych podmiotów do poszczególnych kategorii ${ }^{6}$. Co za tym idzie, o możliwości naruszenia wyżej wymienionej zasady można mówić wyłącznie w sytuacji odmiennego potraktowania (dyskryminującego lub faworyzującego) tych samych rodzajowo podmiotów będących w tej samej sytuacji prawnej (tj. gdy w uchwale rady gminy sformułowano różne normy prawne wobec nieruchomości niezamieszkałych charakteryzujących się takimi samymi cechami).

Zgodnie z art. 1 ustawy z dnia 19 lipca 2019 r. o zmianie ustawy o utrzymaniu czystości i porządku w gminach oraz niektórych innych ustaw (Dz.U. 2019,

$5 \quad$ Wyrok NSA z dnia 8 stycznia 2010 r., II OSK 1814/08, LEX nr 597393; zob. też wyrok NSA z dnia 28 października 2011 r., II OSK 1562/10, LEX nr 1151922.

6 Na takie rozumienie konstytucyjnej zasady równości wskazuje się nie tylko w orzecznictwie Sądu Najwyższego (zob. m.in. wyrok SN z dnia 3 lipca 2019 r., II CSK 424/18, LEX nr 2690816), Naczelnego Sądu Administracyjnego (zob. m.in. wyroki NSA: z dnia 25 listopada 2016 r., I OSK 580/15, LEX nr 2258693; z dnia 16 listopada 2011 r., I OSK 607/11, LEX nr 1149395), ale również w doktrynie. 
poz. 1579) ustawodawca wprowadził w ustawie o utrzymaniu czystości i porządku w gminach zmiany, które weszły w życie 6 września 2019 r. W myśl wprowadzonego art. 6 ust. 2c u.c.p.g. „przystąpienie właściciela nieruchomości, na której nie zamieszkują mieszkańcy, z wyłączeniem właściciela nieruchomości, o której mowa w art. 6j ust. 3b, do zorganizowanego przez gminę systemu gospodarowania odpadami komunalnymi jest dobrowolne i następuje na podstawie zgody właściciela nieruchomości wyrażonej w formie pisemnej”.

Zatem w przypadku, gdy rada gminy postanowi o podjęciu uchwały o objęciu nieruchomości niezamieszkałych gminnym systemem odbierania odpadów komunalnych, właściciel nieruchomości ma możliwość wyłączenia się z tego systemu. Jeżeli gmina zamierza objąć nieruchomości niezamieszkałe, uchwała powoduje obligatoryjne objęcie właścicieli nieruchomości, chyba że w ciągu 30 dni od dnia publikacji uchwały właściciel nieruchomości złoży oświadczenie o wyłączeniu się z systemu odbierania odpadów komunalnych zorganizowanego przez gminę i o pozbywaniu się odpadów na podstawie umowy, o której mowa w art. 6 ust. 1 u.c.p.g.

Jak wskazuje się w uzasadnieniu projektu wprowadzonych zmian, aby zapewnić stabilność systemu, rezygnacja z wyłączenia się z systemu odbierania odpadów komunalnych zorganizowanego przez gminę lub wyłączenie się właściciela nieruchomości będą ponownie możliwe w związku z upływem okresu, na jaki została zawarta umowa w sprawie zamówienia publicznego na odbieranie odpadów komunalnych ${ }^{7}$.

Ustawa o utrzymaniu czystości i porządku w gminach, oprócz uregulowania zadań gminy, określa obowiązki właścicieli nieruchomości dotyczące utrzymania czystości i porządku. Jednym z obowiązków nałożonych przez ustawodawcę na właścicieli nieruchomości jest określony w art. 5 ust. 1 pkt 3b u.c.p.g. obowiązek pozbywania się w sposób zgodny z przepisami ustawy i przepisami odrębnymi zebranych na terenie nieruchomości odpadów komunalnych oraz nieczystości ciekłych.

Adresatami wyżej wymienionego obowiązku są wyłącznie właściciele nieruchomości, którzy nie są objęci gminnym systemem gospodarowania odpadami komunalnymi - a więc właściciele nieruchomości, „na których nie zamieszkują mieszkańcy, a powstają odpady komunalne":

- wobec których to właścicieli rada gminy nie wydała uchwały w przedmiocie objęcia ich systemem gospodarowania odpadami komunalnymi przez gminę (art. 6 c ust. 2 u.c.p.g.);

- którzy to właściciele dokonali wyłączenia swojej nieruchomości z systemu odbierania odpadów komunalnych zorganizowanego przez gminę (art. 6c ust. 2 c u.c.p.g. $)^{8}$.

7 Uzasadnienie rządowego projektu ustawy o zmianie ustawy o utrzymaniu czystości i porządku w gminach oraz niektórych innych ustaw, druk nr 3495.

8 A. Jezierska-Markocka, komentarz do art. 6 [w:] A. Jezierska-Markocka, M. Markocki, Ustawa o utrzymaniu czystości i porządku w gminach, Warszawa 2019. 
Zgodnie z art. 6 ust. 1 u.c.p.g. realizacja nałożonego na właścicieli nieruchomości obowiązku została ograniczona wyłącznie do możliwości zawarcia umowy z gminną jednostką organizacyjną odbierającą odpady komunalne od właścicieli nieruchomości lub przedsiębiorcą wpisanym do rejestru działalności regulowanej, prowadzonego przez wójta, burmistrza lub prezydenta miasta właściwego ze względu na miejsce odbierania odpadów komunalnych od właścicieli nieruchomości (zob. art. 9 b ust. 2 u.c.p.g.). Co za tym idzie, właściciel nieruchomości, który nie jest objęty lokalnym systemem odbioru odpadów, ma ustawowy obowiązek pozbywania się odpadów komunalnych zebranych na terenie nieruchomości. Realizacja obowiązku przebiega następująco:

1) właściciel nieruchomości zawiera umowę z gminną jednostką organizacyjną odbierającą odpady komunalne od właścicieli nieruchomości lub przedsiębiorcą wpisanym do rejestru działalności regulowanej;

2) właściciel nieruchomości na podstawie zawartej umowy, o której mowa w pkt 1, dokonuje uiszczania opłat $\mathrm{z}$ tytułu wykonywanej usługi;

3) właściciel nieruchomości dokumentuje wykonanie obowiązku przez okazanie wyżej wymienionej umowy i dowodów płacenia za takie usługi'

Realizacja ustawowego obowiązku właścicieli nieruchomości podlega kontroli przez wójta, burmistrza lub prezydenta miasta (art. 6 ust. 5a u.c.p.g.), natomiast rada gminy może określić w drodze uchwały, w zależności od lokalnych warunków, inne sposoby udokumentowania wykonania wyżej wymienionych obowiązków (art. 6 ust. 1a u.c.p.g.). Można zatem zgodzić się z domniemaniem, że tak długo, jak rada gminy nie wyda takiej uchwały, jakikolwiek inny sposób realizacji obowiązku określonego w art. 5 ust. 1 pkt 3 b u.c.p.g. przez właścicieli nieruchomości, poza wskazanym w art. 6 ust. 1 u.c.p.g., jest niedopuszczalny ${ }^{10}$.

Podsumowując: gmina ma prawo dowolnego kształtowania systemu odbierania odpadów komunalnych w odniesieniu do „właścicieli nieruchomości, na których nie zamieszkują mieszkańcy, a powstają odpady komunalne”. Zgodnie $\mathrm{z}$ art. $6 c$ ust. 2 u.c.p.g. w związku z art. $6 c$ ust. 3 u.c.p.g. rada gminy może w drodze uchwały stanowiącej akt prawa miejscowego postanowić o odbieraniu odpadów komunalnych od wszystkich właścicieli wyżej wymienionych nieruchomości „lub właścicieli określonych nieruchomości, w szczególności nieruchomości na których jest prowadzony określony rodzaj działalności”. W sytuacji, gdy rada gminy podejmie uchwałę w przedmiocie objęcia nieruchomości niezamieszkałych gminnym systemem odbierania odpadów komunalnych, właściciel nieruchomości ma możliwość wyłączenia się z tego systemu.

Właściciel nieruchomości niezamieszkałej, na której powstają odpady komunalne, nieobjęty gminnym systemem gospodarowania odpadami komunalnymi ma ustawowy obowiązek pozbywania się odpadów komunalnych zebranych

9 Ibidem.

10 Ibidem. 
na terenie nieruchomości - poprzez konieczność zawarcia umowy, ponoszenia opłat i dokumentowania wyżej wymienionych okoliczności (art. 5 ust. 1 pkt 3b oraz art. 6 ust. 1 u.c.p.g.). Realizacja wyżej wymienionego obowiązku przez właścicieli nieruchomości podlega kontroli przez wójta, burmistrza lub prezydenta miasta (art. 6 ust. 5a u.c.p.g.). Rada gminy może natomiast określić w drodze uchwały, w zależności od lokalnych warunków, inne sposoby udokumentowania wykonania wyżej wymienionych obowiązków (art. 6 ust. 1a u.c.p.g.).

\section{Bibliografia}

Jezierska-Markocka A., komentarz do art. 6 [w:] A. Jezierska-Markocka, M. Markocki, Ustawa o utrzymaniu czystości i porządku w gminach, Warszawa 2019.

Radecki W., komentarz do art. 6(c) [w:] Utrzymanie czystości i porządku w gminach. Komentarz, Warszawa 2016. 